\title{
Differential Responses of Amino Acids and Soluble Proteins to Heat Stress Associated with Genetic Variations in Heat Tolerance for Hard Fescue
}

\author{
Jinyu Wang \\ Department of Plant Biology and Pathology, Rutgers University, Foran Hall, 59 Dudley Road, New \\ Brunswick, NJ 08901
}

\begin{abstract}
Bo Yuan
Department of Food Science, Rutgers University, Foran Hall, 59 Dudley Road, New Brunswick, NJ 08901

\author{
Yi Xu and Bingru Huang ${ }^{1}$ \\ Department of Plant Biology and Pathology, Rutgers University, Foran Hall, 59 Dudley Road, New \\ Brunswick, NJ 08901
}

\begin{abstract}
AdDitional INDEX wORDs. high temperature, Festuca trachyphylla, metabolites, proteomics
Abstract. Amino acid and protein metabolism are interrelated and both play important roles in plant adaptation to heat stress. The objective of this study was to identify amino acids and soluble proteins associated with genetic variation in heat tolerance of hard fescue (Festuca trachyphylla). According to a previous screening experiment, the hard fescue cultivars Reliant IV and Predator were selected as heat-tolerant and heat-sensitive cultivars, respectively. Plants of these two hard fescue cultivars were exposed to heat stress at $38 / 33{ }^{\circ} \mathrm{C}$ (day/night) or optimal temperature at $21 / 18{ }^{\circ} \mathrm{C}$ in growth chambers. Each cultivar had four replications under each temperature, and the experimental design was a split-plot design, temperature as the main plots and cultivars as the subplots. Under heat stress, 'Reliant IV' exhibited higher turf quality (TQ) and greater membrane stability than 'Predator'. In response to heat stress, total amino acid content increased, whereas total soluble protein content decreased in both cultivars. The greater accumulation of amino acids in 'Reliant IV' was contributed by the greater increase of proteins involved in the glycolysis and the tricarboxylic acid (TCA) cycle that provided carbon skeleton for amino acid synthesis. 'Reliant IV' leaves exhibited greater extent of increases in the content of six individual amino acids (histidine, glutamine, proline, threonine, aspartate, and tryptophan) than 'Predator' under heat stress. Several soluble proteins were upregulated in response to heat stress, to a greater extent in 'Reliant IV' than 'Predator', including the proteins involved in photosynthesis, protein folding, redox hemostasis, stress signaling, stress defense, cell organization, and metabolism. These differentially accumulated free amino acids and soluble proteins could be associated with the genetic variation in heat tolerance of hard fescue.
\end{abstract}

Heat stress is detrimental to plant growth and productivity in most plants, especially in cool-season species. Plant adaptation to heat stress involves profound changes in metabolic, physiological, and molecular processes (Wahid et al., 2007). Amino acid and protein metabolism are among the major metabolic processes going through adjustment during plant adaptation to heat stress (Du et al., 2011; Kaplan et al., 2004; Yamakawa and Hakata, 2010). Understanding the differential changes in both amino acids and proteins between different cultivars of plants contrasting in heat tolerance will enable the identification of the key metabolic processes controlling genetic variations in heat tolerance.

Free amino acids are constituents of proteins and play regulatory roles in abiotic stress responses as signaling molecules, precursor for numerous secondary metabolites, protein chaperone, and osmotic protectants (D’Mello, 2015). Different amino acids exhibited different roles and responded differently

Received for publication 6 Sept. 2017. Accepted for publication 6 Dec. 2017. We wish to acknowledge the funding support by the National Institute of Food and Agriculture, U.S. Department of Agriculture, Specialty Crops Research Initiative, under award number 2012-51181-19932. We also thank Stephanie Rossi and Cathryn Chapman for critical review of the manuscript.

${ }^{1}$ Corresponding author. E-mail: huang@aesop.rutgers.edu. to abiotic stress. For example, proline protects plants from stress damage by serving as compatible osmolyte, regulator for redox homeostasis, and molecular chaperone (Szabados and Savoure, 2010; Verbruggen and Hermans, 2008). The aromatic amino acids (tyrosine, phenylalanine, and tryptophan) serve as precursor for numerous metabolites involved in stress defense, including auxin, melatonin, phenolic compounds, and alkaloids (Dixon, 2001). Glycine is known to be the substrate for respiration and also serve as a precursor for the glycine betaine, which is a well-known stress protector (Holmström et al., 2000; Oliver et al., 1990; Sakamoto and Murata, 2002). Glutamate may act as a signaling molecule in root architecture (Walch-Liu et al., 2006), nitrogen and carbon metabolism (Lam et al., 2006), and interact with the abscisic acid signaling system (Kang et al., 2004). In addition, a previous metabolic study reported the accumulation of some amino acids in response to heat stress, including alanine, valine, leucine, asparagine, lysine, methionine, isoleucine, and threonine (Du et al., 2011; Kaplan et al., 2004). However, major amino acids conferring heat tolerance in cool-season grass species are not well documented.

Proteins play a central role in heat tolerance of plants, such as serving as the enzymes in metabolism pathway, the regulators 
and components of transcription and translation machinery, and the components for plasma membrane, cell cytoskeleton, and intracellular compartments (Kosová et al., 2011). Most previous analysis of proteome has been applied on plant response to short-term heat shock (hours) (Han et al., 2009; Lee et al., 2007; Li et al., 2013; Zhang et al., 2013b). The proteomic response to heat shock has been illustrated as the upregulation of the proteins involved in various processes, such as energy metabolism [e.g., uridine diphosphate (UDP)-glucose pyrophosphorylase, pyruvate dehydrogenase, and transketolase], chaperone function [e.g., heat shock protein (HSP) 110, HSP90, HSP70, HSP60, and small HSP], and redox homeostasis (e.g., dehydroascorbate reductase, thioredoxin h-type, and chloroplast precursors of superoxide dismutase) (Baniwal et al., 2004; Kosová et al., 2011; Lee et al., 2007; Li et al., 2013). Whereas many studies have found the increased or decreased content or abundance of different proteins in response to heat stress, few studies have examined both amino acids and proteins in relation to the genetic variations for heat tolerance, although amino acids are the constituents of proteins and their content is closely related to protein metabolism.

The fine fescue family is comprised of several species and subspecies, including hard fescue, sheep fescue (Festuca ovina), slender creeping red fescue (Festuca rubra), strong creeping red fescue ( $F$. rubra rubra gunuina), and chewings fescue (F. rubra ssp. commutata) and is a widely used turfgrass in low-maintenance areas because of their superior abiotic stress tolerance, including heat stress, among cool-season turfgrass species. Physiological analysis of the 26 cultivars of the five fine fescue species demonstrated a wide range of the genetic variability in heat tolerance among the fine fescue species and cultivars; the hard fescue was among the most tolerant of the five fine fescue species with 'Reliant IV' and 'Predator' selected as the most heat-tolerant and heat-sensitive hard fescue cultivars (Wang et al., 2017a). Analysis of membrane constituents has identified some membrane proteins, fatty acids, and sterol associated with the genetic variations in heat tolerance between two cultivars (Reliant IV and Predator) of hard fescue contrasting in heat tolerance (Wang et al., $2017 \mathrm{~b}$ ). The objective of this study was to identify the major amino acids and soluble proteins associated with the genetic variations in heat tolerance in two cultivars of hard fescues. Such information will complement the previous findings with physiological traits, membrane proteins, and lipid metabolism and enhance further understanding of the mechanisms of heat tolerance in cool-season turfgrass species.

\section{Materials and Methods}

Plant materials and growth conditions. Two hard fescue cultivars were used in this study-Reliant IV and Predator. A previous physiological analysis of 26 fine fescue cultivars for their responses to heat stress found that 'Reliant IV' exhibited greater heat tolerance than 'Predator' (Wang et al., 2017a). A total of 30 tillers were planted in each plastic containers $(15 \mathrm{~cm}$ depth and $14 \mathrm{~cm}$ diameter) filled with sterile sand autoclaved at $121{ }^{\circ} \mathrm{C}$ for $60 \mathrm{~min}$ on 1 Mar. 2015. Plants were established for $56 \mathrm{~d}$ in a greenhouse with an average day/night temperature of $23 / 20{ }^{\circ} \mathrm{C}$ and $710 \mu \mathrm{mol} \cdot \mathrm{m}^{-2} \cdot \mathrm{s}^{-1}$ photosynthetically active radiation $(P A R)$ from sunlight and supplemental lighting from 1 Mar. 2015 to 25 Apr. 2015. The plants were irrigated daily, trimmed twice per week to maintain $7-\mathrm{cm}$ canopy height, and fertilized every $4 \mathrm{~d}$ with half-strength Hoagland's nutrient solution (Hoagland and Arnon, 1950). After the establishment period, the plants were transferred to controlled-environment growth chambers (Environmental Growth Chambers, Chagrin Falls, OH) controlled at $22 / 18{ }^{\circ} \mathrm{C}$ (day/night), $650 \mu \mathrm{mol} \cdot \mathrm{m}^{-2} \cdot \mathrm{s}^{-1}$ $P A R, 60 \%$ relative humidity, and 12 -h photoperiod for $7 \mathrm{~d}$ to allow for plant acclimation to growth chamber conditions before stress imposition.

Treatments AND EXPerimental Design. Plants for both cultivars were exposed to heat stress at $38 / 33{ }^{\circ} \mathrm{C}$ (day/night) or maintained under nonstress control conditions at $22 / 18{ }^{\circ} \mathrm{C}$ (day/night) for $28 \mathrm{~d}$ from 4 May 2015 to 1 June 2015. Each temperature treatment was repeated in four growth chambers (four growth chambers for control temperature and four growth chambers for heat-stress temperature) and each cultivar had four replicates (pots), which were randomly placed, within each growth chamber. The experimental design was a split-plot design with temperature as the main plots and cultivars as the subplots. All cultivars were arranged randomly within each growth chamber and were relocated among the four growth chambers used for same temperature treatment every $3 \mathrm{~d}$ to avoid possible confounding effects of unique growth chamber environmental variations from occurring.

Physiological measurements. Turf quality and electrolyte leakage (EL) were measured at 7, 14, 21, and $28 \mathrm{~d}$ of heat stress. The TQ rating was performed to evaluate overall turfgrass performance on a scale of 1 to 9 , with 1 being brown and desiccated turf, 6 being the minimal acceptable level, and 9 being green and healthy turf. The ratings were based on parameters such as uniformity, visual attractiveness, leaf color, and canopy density.

Leaf membrane stability was estimated by measuring EL. About $0.2 \mathrm{~g}$ leaf tissue was collected, rinsed with deionized water, and placed in a test tube containing $30 \mathrm{~mL}$ deionized water. The tubes were agitated on a shaker for $12 \mathrm{~h}$ and initial conductance $\left(C_{\mathrm{i}}\right)$ of the incubation solution measured using a conductivity meter (Yellow Springs Instrument, Yellow Springs, $\mathrm{OH}$ ). Leaf tissue was then killed by autoclaving at $121^{\circ} \mathrm{C}$ for $20 \mathrm{~min}$, agitated for $12 \mathrm{~h}$, and maximal conductance $\left(C_{\max }\right)$ of the incubation solution was measured. Plant EL was calculated using the formula $\left(C_{\mathrm{i}} / C_{\max }\right) \times 100$ (Blum and Ebercon, 1981).

Protein Extraction and SeParation. Protein extraction was based on the method by Molloy et al. (1998) with modifications. About $0.5 \mathrm{~g}$ leaf tissue was homogenized with $2 \mathrm{~mL}$ of $40 \mathrm{~mm}$ 2-amino-2-(hydroxymethyl)-1,3-propanediol (tris base) $(\mathrm{pH} 7.6)$ and $0.15 \mathrm{M} \mathrm{NaCl}$ extraction buffer. The homogenate was centrifuged at $10,000 \mathrm{~g}_{\mathrm{n}}$ for $15 \mathrm{~min}$ at $4{ }^{\circ} \mathrm{C}$. The supernatant contained the soluble protein, whereas the pellet contained the membrane protein. The soluble protein was precipitated at $-20{ }^{\circ} \mathrm{C}$ in $8 \mathrm{~mL}$ of acetone with $0.07 \% 2$ mercaptoethanol for $12 \mathrm{~h}$ and then centrifuged for $15 \mathrm{~min}$ at $8500 g_{\mathrm{n}}$ at $4{ }^{\circ} \mathrm{C}$. The $8 \mathrm{~mL}$ of ice-cold acetone containing $0.07 \%$ 2-mercaptoethanol was added to the resulting pellet and stored at $-20{ }^{\circ} \mathrm{C}$ for $2 \mathrm{~h}$. The pellet was washed three times with $0.07 \%$ 2-mercaptoethanol-acetone solution. The pellet was then resuspended in $1 \mathrm{~mL}$ of $8 \mathrm{M}$ urea, $2 \mathrm{M}$ thiourea, $2 \% 3-[(3-$ cholamidopropyl)dimethylammonio]-1-propanesulfonate (CHAPS), 1\% dithiothreitol (DTT), and 1\% 3/10 biolytes. The protein concentration was determined based on the method by Bradford (1976) using protein assay dye reagent (Bio-Rad Laboratories, Hercules, CA). 
Proteins were separated according to $\mathrm{Xu}$ (Xu et al., 2008) with modifications. Immobilized $\mathrm{pH}$ gradient strips $(\mathrm{pH} 3-10$, linear gradient $13 \mathrm{~cm}$ ) were rehydrated in $250 \mathrm{~mL}$ rehydration buffer containing $250 \mathrm{mg}$ extracted proteins [8 M urea, $2 \mathrm{M}$ thiourea, $2 \%(\mathrm{w} / \mathrm{v})$ CHAPS, $1 \%(\mathrm{v} / \mathrm{v})$ immobilized $\mathrm{pH}$ gradient buffer, $1 \%$ DTT, and $0.002 \%$ bromophenol blue]. The strips were put in an isoelectric focusing system (IPGPhor; GE Healthcare, Piscataway, NJ) and run in $50 \mathrm{~V}$ for $14 \mathrm{~h}, 500 \mathrm{~V}$ for $1 \mathrm{~h}, 1000 \mathrm{~V}$ for $1 \mathrm{~h}, 5000 \mathrm{~V}$ for $1 \mathrm{~h}$, and $8000 \mathrm{~V}$ to a total of $80 \mathrm{kVh}$. After the isoelectric focusing, the strips were equilibrated twice for $15 \mathrm{~min}$ in a buffer containing $6 \mathrm{M}$ urea, 30\% glycerol, 2\% sodium dodecyl sulfate, $0.002 \%$ bromophenol blue, $50 \mathrm{~mm}$ tris base ( $\mathrm{pH} 8.7$ ), and 1\% DTT and then incubated in the same buffer replacing DTT with $2.5 \%$ iodoacetamide. Gel electrophoresis of the second dimension was performed in a $12.5 \%$ sodium dodecyl sulfate polyacrylamide gel and by electrophoresis unit (Hoefer SE 600 Ruby; GE Healthcare). The voltage conditions were $5 \mathrm{~mA}$ for $30 \mathrm{~min}$ and $20 \mathrm{~mA}$ for $6 \mathrm{~h}$ per gel. The gel was then stained by Coomassie blue stain and analyzed using SameSpots software (Nonlinepear, Newcastle on Tyne, UK). The normalized spot volumes of heat stress gels were compared with that of control gels to calculate the abundance change under high temperature. The protein spots with probability value lower than 0.05 were selected and identified using liquid chromatography and tandem mass spectrum by N-Cell (Hong Kong, China).

Free amino aCID EXTRACTION AND ANALysis. Free amino acids were extracted by grinding frozen leave material with liquid nitrogen and $4 \mathrm{~mL}$ of $70 \%$ ethanol. After storage overnight in $4{ }^{\circ} \mathrm{C}$, the samples were centrifuged $\left(10,500 \mathrm{~g}_{\mathrm{n}}\right.$, $10 \mathrm{~min})$. The supernatants were collected, filtered through a membrane $(0.45 \mu \mathrm{m}$ polytetrafluoroethylene membrane), concentrated under vacuum, and stored in $-20{ }^{\circ} \mathrm{C}$ (Rozan et al., 2000).

The free amino acid content of the extract was analyzed by a high-performance liquid chromatography (HPLC) gradient system with precolumn phenylisothiocyanate (PITC) derivatization (Khan et al., 1994). Buffer A consisting of $0.1 \mathrm{M}$ ammonium acetate and buffer $\mathrm{B}$ consisting of 0.1 ammonium acetate, acetonitrile, and methanol (44:46:10 v/v) were used (Rozan et al., 2000). For sample derivatization, $100 \mu \mathrm{L}$ of the extract was removed and dried under vacuum $\left(37^{\circ} \mathrm{C}\right)$. Twenty microliters of the first reagent [methanol, water, and triethylamine $(2: 2: 1 \mathrm{v} / \mathrm{v})]$ was added and then dried under vacuum. Then the sample was reacted with $30 \mu \mathrm{L}$ of the PITC reagent [methanol, PITC, water, and triethylamine $(7: 1: 1: 1 \mathrm{v} / \mathrm{v})]$ at room temperature for $20 \mathrm{~min}$ before drying under vacuum. The derivatized samples were then redissolved in $1 \mathrm{~mL}$ of the buffer A. The sample was injected into HPLC/mass selective detector (1100 series; Agilent Technologies, Santa Clara, CA) equipped with an autodegasser, quaternary pump, autosampler, column thermostat, and a diode array detector. The gradients started with $10 \% \mathrm{~B}$ at $0 \mathrm{~min}$, up to $17.5 \%$ at $3 \mathrm{~min}, 21 \%$ at $5.5 \mathrm{~min}, 35 \%$ at $8 \mathrm{~min}$, and $100 \%$ at $28 \mathrm{~min}$, followed by $10 \mathrm{~min}$ column equilibration with the starting mobile phase proportion. The column used was $150 \times 4.6 \mathrm{~mm}, 5 \mu \mathrm{m}$ (Zorbax Eclipse XDB-C8; Agilent Technologies), set at $28^{\circ} \mathrm{C}$. The absorbance at $254 \mathrm{~nm}$ was used for calculations. Individual standards were purchased from Sigma-Aldrich (St. Louis, MO) and prepared as described previously.

Statistical anAlysis. Treatment effects, cultivar variations, and the interaction between temperature treatment and cultivars were determined by the analysis of variance using the general linear model procedure of SAS (version 9.3; SAS Institute, Cary, NC). The differences between treatment means and cultivars were separated by Fisher's protected least significance difference test at $0.05 P$ level.

\section{Results}

Differential PHYSIOLOGICAL RESPONSE TO HEAT STRESS BETWEEN HEAT-TOLERANT AND HEAT-SENSITIVE CULTIVARS. Overall turf performance was evaluated by TQ, whereas cell membrane stability and integrity was evaluated by EL. A significant decrease of TQ was detected at $7 \mathrm{~d}$ of heat treatment for 'Predator', whereas not until $14 \mathrm{~d}$ for 'Reliant IV' (Fig. 1A). The significant differences in TQ between 'Reliant IV' and 'Predator' were detected at 7, 14, 21, and 28 d of heat treatment, with 'Reliant IV' exhibiting higher TQ than 'Predator'. At the end of heat treatment, the TQ of 'Reliant IV' and 'Predator' dropped to 5.6 and 3.8 , respectively.

A significant increase of EL was detected at $14 \mathrm{~d}$ of heat treatment for 'Predator', whereas not until $21 \mathrm{~d}$ for 'Reliant IV' (Fig. 1B). The significant differences in EL between 'Reliant IV' and 'Predator' were observed from the $14 \mathrm{~d}$ of heat treatment, with 'Reliant IV' exhibiting lower EL than 'Predator'.
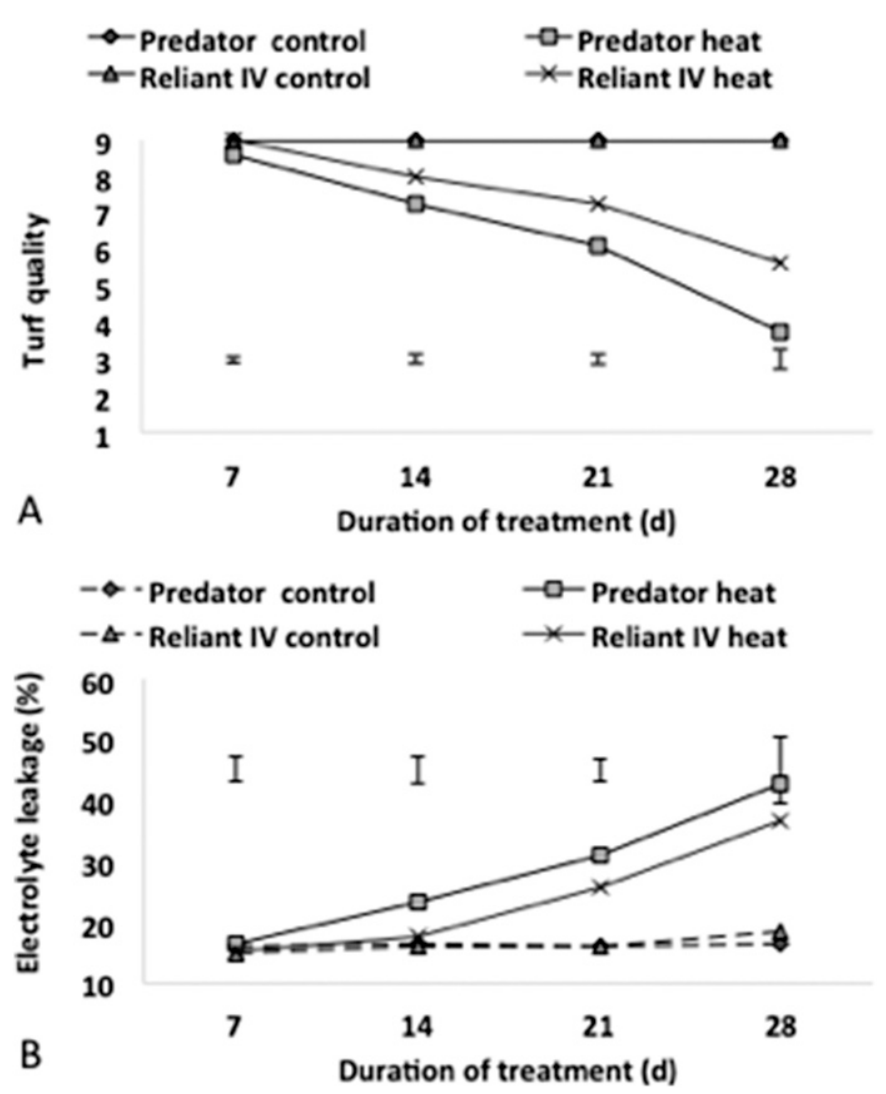

Fig. 1. (A) Turf quality and (B) electrolyte leakage of 'Reliant IV' and 'Predator' hard fescue under heat stress vs. control (e.g., 'Reliant IV' heat vs. 'Reliant IV' control) at 7, 14, 21, and $28 \mathrm{~d}$. Turf quality was rated visually to evaluate overall turfgrass performance on the scale of 1 to 9 , with 1 being the worst and 9 being the best. Vertical bars of the figure indicate least significant difference values $(P \leq 0.05)$ for comparison at a given day of treatment. 
At the end of the heat treatment, the EL of 'Reliant IV' and 'Predator' increased to $37 \%$ and $43 \%$, respectively.

DIFFERENTIAL RESPONSE OF FREE AMINO ACIDS TO HEAT STRESS BETWEEN HEAT-TOLERANT AND HEAT-SENSITIVE CULTIVARS. The variation in free amino acid content exited in hard fescue cultivars under control condition; therefore, the content of free amino acids under heat stress was normalized by that under control condition; the data were expressed as percentage of control in all figures. The content of amino acids under both control and heat condition is provided in Supplemental Table 1. Total free amino acid content increased to $164 \%$ and $143 \%$ of the control under heat stress in 'Reliant IV' and 'Predator', respectively, whereas the changes of individual amino acid content in response to heat stress varied between the two cultivars (Fig. $2)$. Most amino acids showed increased content under heat stress compared with those of the nonstress control, including phenylalanine, tyrosine, tryptophan, serine, glycine, alanine, leucine, valine, lysine, aspartate, threonine, isoleucine, glutamine, histidine, arginine, and proline (Fig. 3). Among them, seven amino acids showed greater increase in 'Reliant IV' than 'Predator', including glutamine, glutamate, proline, histidine, tryptophan, threonine, and aspartate. The decreased content of asparagine was detected under heat stress, with greater decrease in 'Predator' than in 'Reliant IV'.

DIFFERENTIAL RESPONSE OF SOLUBLE PROTEINS TO HEAT STRESS IN HEAT-TOLERANT AND HEAT-SENSITIVE CULTIVARS. The variation in soluble protein content existed in hard fescue cultivars under control condition; therefore, the content of soluble protein under heat stress was normalized by that under control condition; the data were expressed as percentage of control. Total soluble protein content decreased to $76 \%$ and $66 \%$ of the nonstress control under heat stress for 'Reliant IV' and 'Predator', respectively (Fig. 4).

A total of the 30 soluble proteins showing differential expression level in plants exposed to heat stress compared with the control plants in either hard fescue cultivars were identified (Table 1). The UniProt accession number (UniProt Consortium, 2017) for each soluble protein is included in the table. Of the identified protein spots, $34 \%$ were categorized into photosynthesis, $13 \%$ in signaling, $10 \%$ in metabolism, $10 \%$ in stress defense, $7 \%$ in cell organization, $7 \%$ in redox homeostasis, $7 \%$

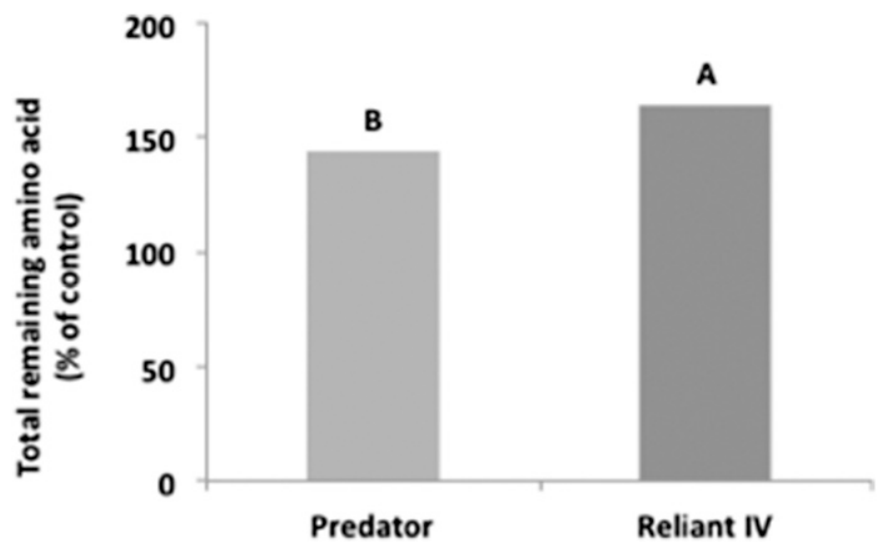

Fig. 2. Remaining total amino acid percentage (total amino acid content after $21 \mathrm{~d}$ of heat stress divided by total amino acid content without heat stress) of 'Reliant IV' and 'Predator' hard fescue. Columns are marked with different letters indicating significant difference between 'Reliant IV' and 'Predator' according to least significant difference $(P \leq 0.05)$ in protein folding, 3\% in DNA processing, $3 \%$ in protein degradation, $3 \%$ in protein synthesis, and 3\% in unknown category (Fig. 5). Several soluble proteins were more upregulated by heat stress in 'Reliant IV' than in 'Predator', including those involved in photosynthesis [glyceraldehyde 3-phosphate dehydrogenase (GAPDH), triosephosphate isomerase, dihydrolipoyl dehydrogenase, malate dehydrogenase, and ribulose-1, 5-bisphosphate carboxylase/oxygenase (RuBisCO) large subunit-binding protein subunit alpha], protein folding (protein disulfide-isomerase), redox hemostasis (catalase), signaling [calcium transporting adenosine triphosphatase (ATPase) and lectin domain containing receptor kinase], stress defense (stromal 70-kDa heat shock-related protein and 20-kDa chaperonin), cell organization (actin, tubulin beta-2 chain), and metabolism (aspartate aminotransferase, formate dehydrogenase, and UDP-sulfoquinovose synthase) (Table 1). Some soluble proteins were downregulated under heat stress, to a lesser extent in 'Reliant IV' than in 'Predator', including those involved in carboxylation in photosynthesis ( $\mathrm{RuBisCO}$ subunits), protein synthesis (50S ribosomal protein L12-2) and signaling (serine/threonine-protein kinase).

\section{Discussion}

Our results in this study confirmed the previous results that 'Reliant IV' exhibited greater heat tolerance than 'Predator' (Wang et al., 2017a). Our previous studies also identified some membrane proteins, such as those involved in electron transport of photosynthesis [adenosine triphosphate (ATP) synthase subunits and cytochrome b6-f complex iron sulfur subunit], signaling (lectin domain-containing receptor kinase A4.2), protein modification (S-acyltransferase), and stress defense (disease resistance protein 1) could contribute to the differential level of heat tolerance between the two cultivars of hard fescues (Wang et al., 2017b). As membrane proteins and soluble proteins play distinct roles in plant growth and stress adaptation, it is also important to understand major soluble proteins and associated amino acids in relation to heat tolerance. In this study, we have found less decreased total soluble protein content and greater increased total amino acid content under heat stress in 'Reliant IV' than in 'Predator', indicating the differential accumulation of soluble proteins and free amino acids could be associated with the genetic variations in heat tolerance in hard fescue. The metabolic functions of these amino acids and soluble proteins related to heat tolerance are discussed in the following paragraphs.

FREE AMINO ACIDS ASSOCIATED WITH HEAT TOLERANCE IN HARD FESCUE. Individual amino acids exhibited differential responses to heat stress in two hard fescue cultivars, but most have shown increased content under heat stress in this study (Fig. 6).

An overall upregulation of amino acids in glutamate family has been observed, with the greater extent of increase in 'Reliant IV' for glutamate, histidine, glutamine, and proline. Glutamate and glutamine play important roles in amino acid synthesis as they are directly involved in ammonium assimilation and transfer the amino group to all other amino acids (Lea and Ireland, 1999). Proline plays an important role in stress tolerance, as compatible osmolyte, the regulator for redox homeostasis and molecular chaperone (Szabados and Savoure, 2010; Verbruggen and Hermans, 2008). Arginine serves as the precursor of polyamines, which acts as reactive oxygen species (ROS)-scavenging and as membrane protectors in stress 

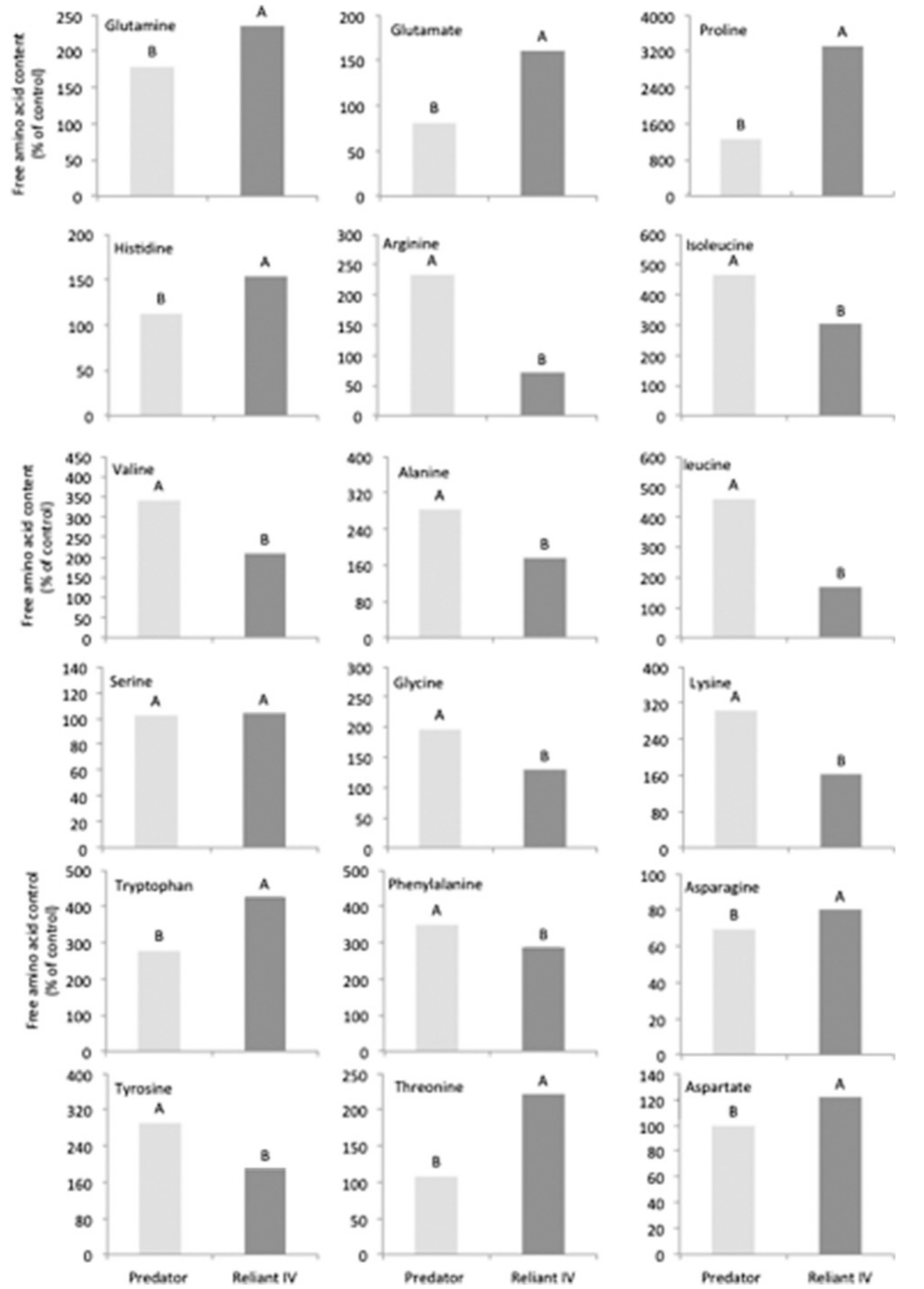

Fig. 3. Remaining free amino acid percentage (free amino acid content after $21 \mathrm{~d}$ of heat stress divided by free amino acid content without heat stress) of 'Reliant IV' and 'Predator' hard fescue. Columns are marked with different letters indicating significant difference between 'Reliant IV' and 'Predator' according to least significant difference $(P \leq 0.05)$. The specific type of amino acid is labeled on the top left corner of each subfigure.

tolerance (Lea et al., 2007). Histidine is required for plant growth and development and serves as metal chelators (Stepansky and Leustek, 2006). Our result indicated that upregulation of the amino acids in glutamate family (glutamate, glutamine, proline, and histidine) could play positive roles in regulating heat tolerance in hard fescue.

The content of aspartate and threonine showed greater increase in 'Reliant IV' than in 'Predator' under heat stress.
Aspartate is the precursor that leads to synthesis of asparagine and aspartate-derived amino acids (lysine, methionine, threonine, and isoleucine) (D’Mello, 2015). Asparagine is a major nitrogen transport compound in xylem and phloem (Lea et al., 2007). The synthesis of asparagine from aspartate is catalyzed by asparagine synthetase through an ATP-dependent transfer of amide group from glutamate to aspartate (D'Mello, 2015). The content of several aspartate-derived amino acids, asparagine, lysine, threonine, and isoleucine, also increased under heat stress. Our result indicated that the accumulation of aspartate and threonine was positively associated with heat tolerance in hard fescue.

Three amino acids categorized into aromatic amino acid family, including tyrosine, phenylalanine, and tryptophan, exhibited the differential responses to heat stress for the two hard fescue cultivars, with the greater accumulation of tryptophan and the less accumulation of tyrosine and phenylalanine in 'Reliant IV' compared with 'Predator'. All these three amino acids are derived from shikimate pathway and serve as the precursor for numerous metabolites. Tryptophan is a precursor for most indole compounds, including two plant hormones auxin and melatonin (Tzin and Galili, 2010), which promote plant tolerance to various abiotic stress (Arnao and Hernández-Ruiz, 2013; Lei et al., 2004; Peyrot and Ducrocq, 2008; Zhang et al., 2013a). Phenylalanine is a precursor for phenylpropanoid biosynthesis pathway, which generates numerous phenolic compounds (Vogt, 2010). Tyrosine is a precursor of isoquinoline alkaloids, tyramine and tocochromanols (vitamin E) (Radwanski and Last, 1995). The greater accumulation of tryptophan and the less accumulation of tyrosine and phenylalanine in 'Reliant IV' could facilitate its superior heat tolerance to 'Predator' by involving in hormone and secondary metabolism.

In contrast to the results discussed previously, the content of several amino acids including glycine, alanine, valine, and leucine, exhibited greater increases in 'Predator' than in 'Reliant IV' under heat stress. Glycine is an important substrate for respiration and also serves as a precursor for glycine betaine, which is known to accumulate in response to various abiotic stresses (Holmström et al., 2000; Oliver et al., 1990; Sakamoto 


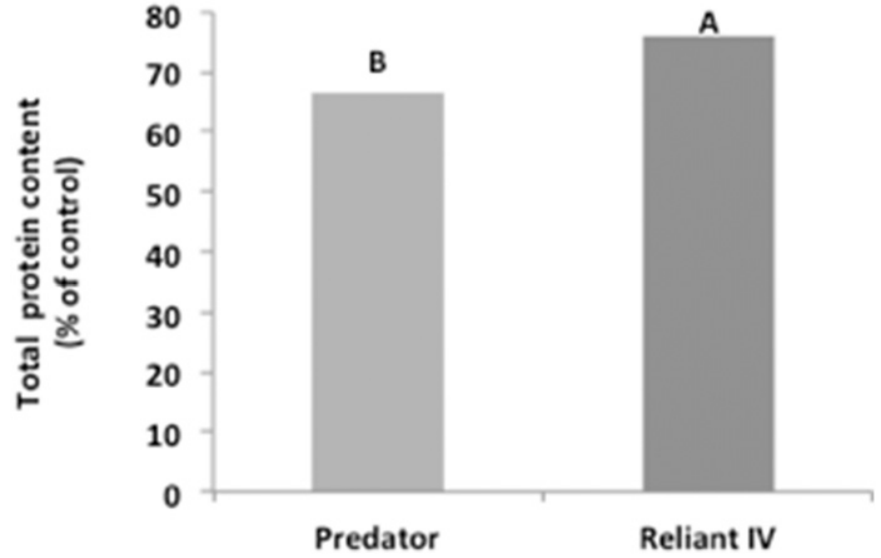

Fig. 4. Remaining total soluble protein content percentage (total soluble protein content after $21 \mathrm{~d}$ of heat stress divided by total soluble protein content without heat stress) of 'Reliant IV' and 'Predator' hard fescue. Columns are marked with different letters indicating significant difference between 'Reliant IV' and 'Predator' according to least significant difference $(P \leq 0.05)$.

and Murata, 2002). The increased content of alanine, valine, and leucine in response to heat stress has been previously reported in arabidopsis (Arabidopsis thaliana) (Kaplan et al., 2004) and has been suggested as a consequence of stressinduced pyruvate accumulation (Good and Zaplachinski, 1994; Rocha et al., 2010). Our finding that 'Predator' showed the greater increase of glycine, alanine, leucine, and valine under heat stress than 'Reliant IV' may reflect its greater level of physiological stress or sensitivity in response to heat stress.

SOLUbLE PROTEINS ASSOCIATED WITH HEAT TOLERANCE IN HARD FESCUE. Whereas the total content of proteins decreased in both hard fescue cultivars under heat stress, the content of some individual proteins either remained unchanged, increased, or decreased and also exhibited the differential response between the two cultivars under heat stress. Therefore, identification of specific soluble proteins with important biological functions is of great significance for better understanding the metabolic pathways or processes underlying genetic variations in heat tolerance.

A large proportion of differential-expressed soluble proteins involved in energy metabolism, including $\mathrm{RuBisCO}$ large and small chain, RuBisCO large subunit-binding protein subunit alpha, dihydrolipoyl dehydrogenase, malate dehydrogenase, GAPDH, and triosephosphate isomerase. RuBisCO large subunit and small subunit are the major components for RuBisCO, whereas RuBisCO-binding protein serves as a chaperon in the RuBisCO assembly and in stabilization under heat stress (Spreitzer and Salvucci, 2002). The better maintenance of RuBisCO under heat stress in 'Reliant IV' could assist in maintaining photosynthesis under heat stress. Respiration provided energy for biosynthesis, cellular maintenance, and active transport in plants and also for stress defense under stress conditions (Taiz and Zeiger, 2010). More importantly, the respiration can also provide carbon skeleton for various metabolites, including amino acids (Fig. 6). In this study, the greater upregulation of dihydrolipoyl dehydrogenase, malate dehydrogenase, GAPDH, and triosephosphate isomerase were detected under heat stress in 'Reliant IV' compared with 'Predator'. The triosephosphate isomerase and GAPDH are the key enzymes in glycolysis, which catalyze the converting from dihydroxyacetone phosphate to glyceraldehyde 3-phosphate and from glyceraldehyde 3-phosphate into 1,3-bisphosphoglycerate, respectively. Dihydrolipoyl dehydrogenase and malate dehydrogenase are involved in the TCA cycle. The dihydrolipoyl dehydrogenase is a primary component of pyruvate dehydrogenase complex, which involved in transferring carbon from glycolysis to the TCA cycle (Reid et al., 1977). Malate dehydrogenase catalyzes the reversible reaction from malate to oxaloacetic acid (Hodges, 2002). A greater increase of enzymes involved in glycolysis and the TCA cycle in 'Reliant IV' could be associated with its better heat tolerance by providing carbon skeleton for amino acid synthesis for stress defense.

In addition, the upregulation of two enzymes (superoxide dismutase and catalase) involved in ROS scavenging was detected under heat stress, with the greater upregulation of catalase in 'Reliant IV' than 'Predator'. Superoxide dismutase catalyzes the conversion from $\mathrm{O}_{2-}$ to $\mathrm{H}_{2} \mathrm{O}_{2}$ and the generated $\mathrm{H}_{2} \mathrm{O}_{2}$ was subsequently split into water and oxygen by catalase (Ahmad et al., 2010). The superoxide dismutase and catalase showed increased enzyme activity in response to heat stress (Chaitanya et al., 2002; Gill and Tuteja, 2010) with a positive relationship between the upregulation level of catalase activity and heat tolerance (Xu et al., 2015). The greater upregulation of catalase in 'Reliant IV' would protect plants from oxidative damage, contributing to better tolerance to heat stress.

It has been long known that heat leads to increased expression of the proteins with chaperone functions, such as HSP. The $70-\mathrm{kDa}$ HSP is a prominent family that has essential function in preventing aggregation, assisting refolding, and facilitating the proteolytic degradation of non-native proteins under stress conditions (Wang et al., 2004). The 20-kDa chaperone, as a small HSP, involves in stabilizing and preventing non-native protein aggregation through hydrophobic interaction (Lee and Vierling, 2000; Veinger et al., 1998). In addition, compared with 'Predator', 'Reliant IV' had the greater accumulation of other proteins involved in protein folding, such as protein disulfide isomerase (Hatahet and Ruddock, 2009; Pemberton, 2006; Wilkinson and Gilbert, 2004) and protein synthesis, such as the chloroplast 50S ribosomal protein L12-2 (Wittmann, 1982) which involved in the synthesis of the subunits of photosystem I, photosystem II, ATPase, and cytochrome b6f and RuBisCO large subunit (Ridley et al., 1967). The greater upregulation of HSP70, HSP20, protein disulfide isomerase, and chloroplast $50 \mathrm{~S}$ ribosomal protein L12-2 in 'Reliant IV' suggested the importance of those proteins in protecting hard fescue plants from heat damages. For the protein assisting in pre-ribosomal RNA processing and RNA stabilization (Zchut et al., 2003), glycine-rich RNAbinding protein exhibited increased abundance level in response to heat stress in both hard fescue cultivars, although no cultivar difference was detected in this study. Our results indicated that the upregulation of glycine-rich RNA-binding protein could play potential roles in heat responses, but would not account for variation of heat tolerance in hard fescue.

An increased accumulation of the proteins for the enzymes involved in metabolism (UDP-sulfoquinovose synthase, formate dehydrogenase, and aspartate aminotransferase) indicated a metabolic adjustment in response to heat stress in hard fescue. The UDP-sulfoquinovose synthase is a soluble enzyme located in chloroplast stroma and plays a regulatory role in the synthesis of the sulfolipid (Shimojima, 2011), which stabilizes protein complexes, including photosystem II (Minoda et al., 2003) and 
Table 1. Fold changes of protein abundance under $21 \mathrm{~d}$ of heat stress treatment compared with control in 'Predator' and 'Reliant IV' hard fescue. Heat stress significantly decreased $(-)$ or increased $(+)$ protein abundance compared with control according to least significant difference $(P \leq$ $0.05)$.

\begin{tabular}{|c|c|c|c|c|c|}
\hline \multirow[b]{2}{*}{ Spot no. } & \multirow[b]{2}{*}{ Protein description } & \multirow{2}{*}{$\begin{array}{l}\text { UniProt } \\
\text { accession no. }\end{array}$} & \multirow[b]{2}{*}{ Protein score } & \multicolumn{2}{|c|}{$\begin{array}{l}\text { Fold change compared with control under } 21-d \text { heat } \\
\text { stress treatment }\end{array}$} \\
\hline & & & & Predator & Reliant IV \\
\hline \multicolumn{6}{|c|}{ Cell organization } \\
\hline 953 & Actin & B1P763 & 366.19 & $\mathrm{NS}^{\mathrm{y}}$ & 2.5 \\
\hline 1611 & Tubulin beta- 2 chain & M8AFS1 & 107.3 & 3.5 & 5.1 \\
\hline \multicolumn{6}{|c|}{ DNA processing } \\
\hline 66 & DNA helicase & MOUEL0 & 176.19 & 6 & 5.2 \\
\hline \multicolumn{6}{|c|}{ Metabolism } \\
\hline 1312 & Aspartate aminotransferase & W5G5A6 & 916.86 & NS & 2.6 \\
\hline 1195 & $\begin{array}{l}\text { Formate dehydrogenase, } \\
\text { mitochondrial }\end{array}$ & N1R356 & 376.76 & 2.2 & 2.4 \\
\hline 1356 & $\begin{array}{l}\text { UDP-sulfoquinovose } \\
\text { synthase, chloroplastic }\end{array}$ & R7W2K9 & 114.29 & NS & 2.9 \\
\hline \multicolumn{6}{|c|}{ Energy metabolism } \\
\hline 1606 & $\begin{array}{l}\text { Dihydrolipoyl } \\
\text { dehydrogenase }\end{array}$ & I1HF32 & 71.21 & NS & 3 \\
\hline 1608 & $\begin{array}{l}\text { Dihydrolipoyl } \\
\text { dehydrogenase }\end{array}$ & I1HLI3 & 736.6 & 1.3 & 2.4 \\
\hline 1195 & $\begin{array}{l}\text { Glyceraldehyde-3- } \\
\text { phosphate dehydrogenase } \\
\text { (GAPDH) }\end{array}$ & C9S527 & 1818.27 & 2.2 & 2.4 \\
\hline 1318 & GAPDH & F2CUW2 & 141.67 & NS & 3.7 \\
\hline 1143 & Malate dehydrogenase & M0Z0D3 & 243.45 & NS & 2.5 \\
\hline 1086 & Malate dehydrogenase & A0A096UKG6 & 33.27 & 2.3 & 2.2 \\
\hline 2058 & $\begin{array}{l}\text { Ribulose bisphosphate } \\
\text { carboxylase large chain }\end{array}$ & B0YIE1 & 492.78 & -2 & -1.8 \\
\hline 120 & $\begin{array}{l}\text { Ribulose bisphosphate } \\
\text { carboxylase small chain }\end{array}$ & Q9SBU5 & 142.71 & -2.2 & -1.5 \\
\hline 1630 & $\begin{array}{l}\text { RuBisCO large subunit- } \\
\text { binding protein subunit } \\
\text { alpha, chloroplastic }\end{array}$ & P08823 & 5848.41 & NS & 3.2 \\
\hline 763 & Triosephosphate isomerase & A0A077RSI3 & 136.62 & 1.6 & 2.3 \\
\hline \multicolumn{6}{|c|}{ Protein degradation } \\
\hline 754 & $\begin{array}{l}\text { E3 ubiquitin-protein ligase } \\
\text { UPL4 }\end{array}$ & M7YJY4 & 198.75 & 2.3 & 1.8 \\
\hline \multicolumn{6}{|c|}{ Protein folding } \\
\hline 476 & $\begin{array}{l}\text { Peptidyl-prolyl cis-trans } \\
\text { isomerase }\end{array}$ & I1HN82 & 46.54 & 1.5 & 1.5 \\
\hline 1660 & Protein disulfide isomerase & A0A024FR39 & 1103.44 & NS & 2.8 \\
\hline \multicolumn{6}{|c|}{ Protein synthesis } \\
\hline 377 & $\begin{array}{l}\text { 50S ribosomal protein } \\
\text { L12-2, chloroplastic }\end{array}$ & M8BN49 & 125.53 & -2.9 & -1.5 \\
\hline \multicolumn{6}{|c|}{ Redox homeostasis } \\
\hline 794 & Catalase & I1HWC4 & 589.18 & NS & 2.2 \\
\hline 247 & $\begin{array}{l}\text { Superoxide dismutase } \\
\quad[\mathrm{Cu}-\mathrm{Zn}]\end{array}$ & I1GRB8 & 333.11 & 2.2 & 1.6 \\
\hline \multicolumn{6}{|l|}{ Signaling } \\
\hline 1612 & $\begin{array}{l}\text { Calcium-transporting } \\
\text { ATPase }\end{array}$ & M8BEP9 & 41.46 & & 1.6 \\
\hline 1611 & $\begin{array}{l}\text { Lectin domain-containing } \\
\text { receptor kinase A4.2 }\end{array}$ & M8D1L3 & 77.86 & 3.5 & 5.1 \\
\hline 760 & $\begin{array}{l}\text { Leucine-rich repeat } \\
\text { receptor-like serine/ } \\
\text { threonine protein kinase }\end{array}$ & M8B4U2 & 83.52 & 2.1 & 1.6 \\
\hline 1671 & $\begin{array}{l}\text { Serine/threonine protein } \\
\text { kinase }\end{array}$ & F2D5V8 & 58.53 & -2.3 & -1.9 \\
\hline
\end{tabular}




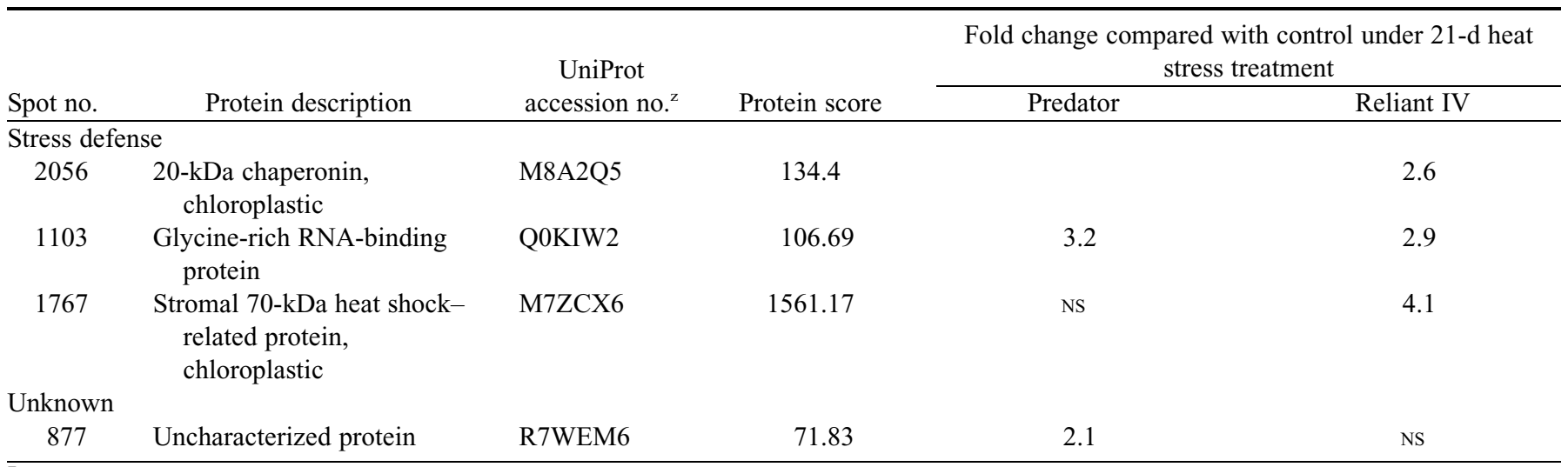

${ }^{\mathrm{z}}$ UniProt Consortium (2017).

${ }^{\mathrm{y}}$ Nonsignificant at $0.05 P$ level.

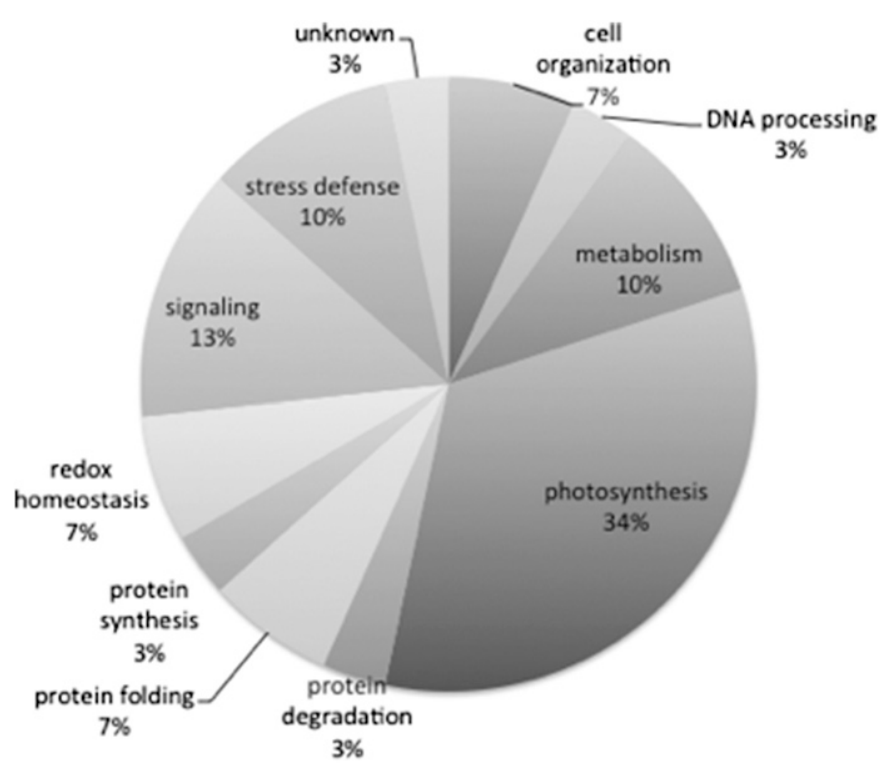

Fig. 5. Functional classification of soluble proteins which are expressed differently after $21 \mathrm{~d}$ of heat stress treatment vs. control (no heat stress treatment) for either 'Reliant IV' or 'Predator' hard fescue.

CF0-CF1 ATPase (Taran et al., 2000). The formate dehydrogenase catalyzes the oxidation of formate (des Francs-Small et al., 1993). The aspartate aminotransferase mediates aspartate synthesis by catalyzing the reversible transamination between glutamate and oxaloacetate to generate aspartate and 2-oxoglutarate (de la Torre et al., 2014). The increased protein abundance of aspartate aminotransferase is consistent with the increase in the content of aspartate and aspartatederived amino acids observed in 'Reliant IV', as discussed previously. Altogether, the greater accumulation of UDPsulfoquinovose synthase, formate dehydrogenase, and aspartate aminotransferase under heat stress in 'Reliant IV' than 'Predator' indicated that a metabolic adjustment for the enhanced synthesis of amino acids and proteins playing roles in stabilizing protein complex and respiratory energy metabolism is important for hard fescue tolerance to heat tolerance.

Cytoskeleton is a complex network that helps maintaining cell shape, cell signaling, and intracellular transportation (Taiz and Zeiger, 2010). The greater upregulation of two major components of cytoskeleton (beta tubulin and actin) was detected under heat stress in 'Reliant IV'. Similar increase was also reported under heat stress in euphrates poplar (Populus euphratica) suggested as a result of cytoskeleton reorganization (Ferreira et al., 2006). Therefore, it is intriguing to speculate cytoskeleton reorganization under heat stress in hard fescue plants.

Four proteins involved in signaling, including receptor kinase (lectin domain-containing receptor kinase A4.2, serine/threonine protein kinase, and leucine-rich repeat receptorlike serine/threonine protein kinase) and calcium-transporting ATPase, exhibited the upregulation in response to heat stress in this study. The receptor-like kinase connects the cell wall, plasma membrane, and cytoskeleton and plays a central role in signaling transduction by accepting external signal and converting it into appropriate outputs such as changes in gene and protein expression and in metabolism (Fujita et al., 2006). Calcium-transporting ATPase is an ATP-dependent calcium pump that transport calcium against its concentration (White and Broadley, 2003). Transient increase of calcium ions has been observed in response to heat stress and suggested to be involved in signaling transduction (Gong et al., 1998). The greater upregulation of lectin domain-containing receptor kinase A4.2 and calcium-transporting ATPase under heat stress in 'Reliant IV' might assist in signaling transduction. However, how the expression level of these two proteins and signaling transduction are related to heat tolerance is not well known.

The upregulation of DNA helicase was detected on heat stress with higher upregulation level in 'Predator'. DNA helicase catalyzes the unwinding of duplex DNA, which is a critical step for replication, repair, recombination, transcription, and translation (Matson et al., 1994). The induction of DNA helicase has been reported under cold and salinity stress and suggested to be involved in stress signaling (Vashisht et al., 2005). The greater extent of the upregulation of DNA helicase in heat-sensitive 'Predator' indicated that higher levels of the DNA damages due to heat stress may require more abundant DNA helicase for repairing the damaged DNA, although the functions of DNA helicase in heat tolerance deserves further investigation.

In summary, the greater accumulation of total free amino acid content and the less-severe decrease of total soluble protein content was observed under heat stress in 'Reliant IV' compared with 'Predator'. Furthermore, 'Reliant IV' showed the greater increase of seven essential amino acids (histidine, glutamine, glutamate, proline, threonine, aspartate, and tryptophan) 


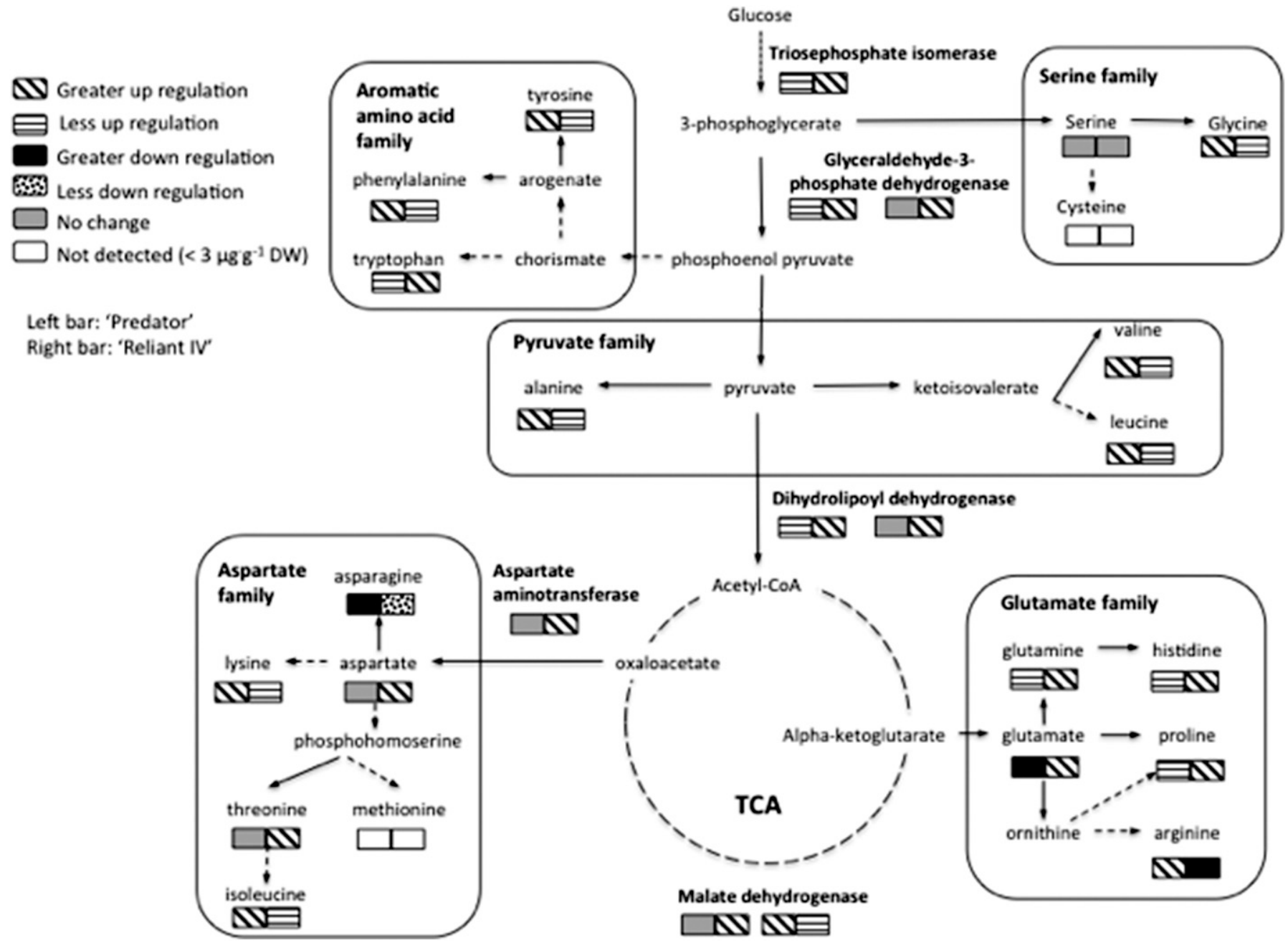

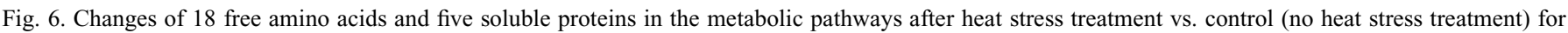
'Reliant IV' and 'Predator' hard fescue. The 18 free amino acids are grouped into five families and labeled in the box, whereas the five soluble proteins are labeled outside the box; TCA $=$ tricarboxylic acid cycle.

and several soluble proteins, including GAPDH, triosephosphate isomerase, dihydrolipoyl dehydrogenase, malate dehydrogenase, $\mathrm{RuBisCO}$ large subunit-binding protein subunit alpha, protein disulfide-isomerase, catalase, calcium-transporting ATPase, lectin domain-containing receptor kinase, stromal $70-\mathrm{kDa}$ heat shock-related protein, 20-kDa chaperonin, actin, tubulin beta-2 chain, aspartate aminotransferase, formate dehydrogenase, and UDP-sulfoquinovose synthase. The differential accumulation of those amino acids and soluble proteins under heat stress between 'Reliant IV' and 'Predator' could be associated with the variation of heat tolerance in hard fescue. The more upregulated amino acids in 'Reliant IV' exposed to heat stress could potentially be incorporated into the biostimulant products used in managing stressed turfgrass. The direct involvement in heat tolerance of the differentially accumulated amino acids and soluble proteins between the two cultivars deserves further investigation.

\section{Literature Cited}

Ahmad, P., C.A. Jaleel, M.A. Salem, G. Nabi, and S. Sharma. 2010. Roles of enzymatic and nonenzymatic antioxidants in plants during abiotic stress. Crit. Rev. Biotechnol. 30:161-175.
Arnao, M.B. and J. Hernández-Ruiz. 2013. Growth conditions influence the melatonin content of tomato plants. Food Chem. 138:12121214.

Baniwal, S.K., K. Bharti, K.Y. Chan, M. Fauth, A. Ganguli, S. Kotak, S.K. Mishra, L. Nover, M. Port, K-D. Scharf, and J. Tripp. 2004. Heat stress response in plants: A complex game with chaperones and more than twenty heat stress transcription factors. J. Biosci. 29:471-487.

Blum, A. and A. Ebercon. 1981. Cell membrane stability as a measure of drought and heat tolerance in wheat. Crop Sci. 21:43-47.

Bradford, M.M. 1976. A rapid and sensitive method for the quantitation of microgram quantities of protein utilizing the principle of protein-dye binding. Anal. Biochem. 72:248-254.

Chaitanya, K., D. Sundar, S. Masilamani, and A.R. Reddy. 2002. Variation in heat stress-induced antioxidant enzyme activities among three mulberry cultivars. Plant Growth Regulat. 36:175-180.

D’Mello, J.F. 2015. Amino acids in higher plants. CABI, Wallingford, UK.

de la Torre, F., R.A. Cañas, M.B. Pascual, C. Avila, and F.M. Cánovas. 2014. Plastidic aspartate aminotransferases and the biosynthesis of essential amino acids in plants. J. Expt. Bot. 65:5527-5534.

des Francs-Small, C.C., F. Ambard-Bretteville, I.D. Small, and R. Rémy. 1993. Identification of a major soluble protein in mitochondria from nonphotosynthetic tissues as NAD-dependent formate dehydrogenase. Plant Physiol. 102:1171-1177. 
Dixon, R.A. 2001. Natural products and plant disease resistance. Nature 411:843-847.

Du, H., Z. Wang, W. Yu, Y. Liu, and B. Huang. 2011. Differential metabolic responses of perennial grass Cynodon transvaalensis $\times$ Cynodon dactylon (C4) and Poa pratensis (C3) to heat stress. Physiol. Plant. 141:251-264.

Ferreira, S., K. Hjernø, M. Larsen, G. Wingsle, P. Larsen, S. Fey, P. Roepstorff, and M.S. Pais. 2006. Proteome profiling of Populus euphratica Oliv. upon heat stress. Ann. Bot. 98:361-377.

Fujita, M., Y. Fujita, Y. Noutoshi, F. Takahashi, Y. Narusaka, K. Yamaguchi-Shinozaki, and K. Shinozaki. 2006. Crosstalk between abiotic and biotic stress responses: A current view from the points of convergence in the stress signaling networks. Curr. Opin. Plant Biol. 9:436-442.

Gill, S.S. and N. Tuteja. 2010. Reactive oxygen species and antioxidant machinery in abiotic stress tolerance in crop plants. Plant Physiol. Biochem. 48:909-930.

Gong, M., A.H. van der Luit, M.R. Knight, and A.J. Trewavas. 1998. Heat-shock-induced changes in intracellular $\mathrm{Ca}^{2+}$ level in tobacco seedlings in relation to thermotolerance. Plant Physiol. 116:429-437.

Good, A.G. and S.T. Zaplachinski. 1994. The effects of drought stress on free amino acid accumulation and protein synthesis in Brassica napus. Physiol. Plant. 90:9-14.

Han, F., H. Chen, X-J. Li, M-F. Yang, G-S. Liu, and S-H. Shen. 2009. A comparative proteomic analysis of rice seedlings under various high-temperature stresses. Biochim. Biophys. Acta 1794:1625-1634.

Hatahet, F. and L.W. Ruddock. 2009. Protein disulfide isomerase: A critical evaluation of its function in disulfide bond formation. Antioxid. Redox Signal. 11:2807-2850.

Hoagland, D.R. and D.I. Arnon. 1950. The water-culture method for growing plants without soil. California Agr. Expt. Bul. 347.

Hodges, M. 2002. Enzyme redundancy and the importance of 2oxoglutarate in plant ammonium assimilation. J. Expt. Bot. 53:905916.

Holmström, K.O., S. Somersalo, A. Mandal, T.E. Palva, and B. Welin. 2000. Improved tolerance to salinity and low temperature in transgenic tobacco producing glycine betaine. J. Expt. Bot. 51:177-185. Kang, J., S. Mehta, and F.J. Turano. 2004. The putative glutamate receptor 1.1 (AtGLR1. 1) in Arabidopsis thaliana regulates abscisic acid biosynthesis and signaling to control development and water loss. Plant Cell Physiol. 45:1380-1389.

Kaplan, F., J. Kopka, D.W. Haskell, W. Zhao, K.C. Schiller, N. Gatzke, D.Y. Sung, and C.L. Guy. 2004. Exploring the temperaturestress metabolome of Arabidopsis. Plant Physiol. 136:4159-4168.

Khan, J.K., Y-H. Kuo, N. Kebede, and F. Lambein. 1994. Determination of non-protein amino acids and toxins in Lathyrus by high-performance liquid chromatography with precolumn phenyl isothiocyanate derivatization. J. Chromatography 687:113-119.

Kosová, K., P. Vítámvás, I.T. Prášil, and J. Renaut. 2011. Plant proteome changes under abiotic stress - Contribution of proteomics studies to understanding plant stress response. J. Proteomics 74:1301-1322

Lam, H.M., Y.A. Chiao, M.W. Li, Y.K. Yung, and S. Ji. 2006. Putative nitrogen sensing systems in higher plants. J. Integr. Plant Biol. 48:873-888.

Lea, P.J. and R.J. Ireland. 1999. Nitrogen metabolism in higher plants, p. 1-48. In: B.K. Singh (ed.). Plant amino acids: Biochemistry and biotechnology. CRC Press, Boca Raton, FL.

Lea, P.J., L. Sodek, M.A. Parry, P.R. Shewry, and N.G. Halford. 2007. Asparagine in plants. Ann. Appl. Biol. 150:1-26.

Lee, D.G., N. Ahsan, S.H. Lee, K.Y. Kang, J.D. Bahk, I.J. Lee, and B.H. Lee. 2007. A proteomic approach in analyzing heat-responsive proteins in rice leaves. Proteomics 7:3369-3383.

Lee, G.J. and E. Vierling. 2000. A small heat shock protein cooperates with heat shock protein 70 systems to reactivate a heat-denatured protein. Plant Physiol. 122:189-198.

Lei, X.Y., R.Y. Zhu, G.Y. Zhang, and Y.R. Dai. 2004. Attenuation of cold-induced apoptosis by exogenous melatonin in carrot suspension cells: The possible involvement of polyamines. J. Pineal Res. 36:126-131.

Li, W., Z. Wei, Z. Qiao, Z. Wu, L. Cheng, and Y. Wang. 2013. Proteomics analysis of alfalfa response to heat stress. PLoS One 8:1-11.

Matson, S.W., D.W. Bean, and J.W. George. 1994. DNA helicases: Enzymes with essential roles in all aspects of DNA metabolism. BioEssays 16:13-22.

Minoda, A., K. Sonoike, K. Okada, N. Sato, and M. Tsuzuki. 2003. Decrease in the efficiency of the electron donation to tyrosine $\mathrm{Z}$ of photosystem II in an SQDG-deficient mutant of Chlamydomonas. FEBS Lett. 553:109-112.

Molloy, M.P., B.R. Herbert, B.J. Walsh, M.I. Tyler, M. Traini, J.C. Sanchez, D.F. Hochstrasser, K.L. Williams, and A.A. Gooley. 1998. Extraction of membrane proteins by differential solubilization for separation using two-dimensional gel electrophoresis. Electrophoresis 19:837-844

Oliver, D.J., M. Neuburger, J. Bourguignon, and R. Douce. 1990. Glycine metabolism by plant mitochondria. Physiol. Plant. 80:487491.

Pemberton, T.J. 2006. Identification and comparative analysis of sixteen fungal peptidyl-prolyl cis/trans isomerase repertoires. BMC Genomics 7:244-274.

Peyrot, F. and C. Ducrocq. 2008. Potential role of tryptophan derivatives in stress responses characterized by the generation of reactive oxygen and nitrogen species. J. Pineal Res. 45:235-246.

Radwanski, E.R. and R.L. Last. 1995. Tryptophan biosynthesis and metabolism: Biochemical and molecular genetics. Plant Cell 7:921934.

Reid, E.E., P. Thompson, C.R. Lyttle, and D.T. Dennis. 1977. Pyruvate dehydrogenase complex from higher plant mitochondria and proplastids. Plant Physiol. 59:854-858.

Ridley, S.M., J.P. Thornber, and J.L. Bailey. 1967. A study of the water-soluble proteins of spinach beet chloroplasts with particular reference to fraction I protein. Biochim. Biophys. Acta Protein Struct. 140:62-79.

Rocha, M., F. Licausi, W.L. Araujo, A. Nunes-Nesi, L. Sodek, A.R. Fernie, and J.T. van Dongen. 2010. Glycolysis and the tricarboxylic acid cycle are linked by alanine aminotransferase during hypoxia induced by waterlogging of Lotus japonicus. Plant Physiol. 152:1501-1513.

Rozan, P., Y-H. Kuo, and F. Lambein. 2000. Free amino acids present in commercially available seedlings sold for human consumption: A potential hazard for consumers. J. Agr. Food Chem. 48:716-723.

Sakamoto, A. and N. Murata. 2002. The role of glycine betaine in the protection of plants from stress: Clues from transgenic plants. Plant Cell Environ. 25:163-171.

Shimojima, M. 2011. Biosynthesis and functions of the plant sulfolipid. Prog. Lipid Res. 50:234-239.

Spreitzer, R.J. and M.E. Salvucci. 2002. Rubisco: Structure, regulatory interactions, and possibilities for a better enzyme. Annu. Rev. Plant Biol. 53:449-475.

Stepansky, A. and T. Leustek. 2006. Histidine biosynthesis in plants. Amino Acids 30:127-142.

Szabados, L. and A. Savoure. 2010. Proline: A multifunctional amino acid. Trends Plant Sci. 15:89-97.

Taiz, L. and E. Zeiger. 2010. Plant physiology. 5th ed. Sinauer Assoc., Sunderland, MA.

Taran, N., A. Okanenko, and N. Musienko. 2000. Sulpholipid reflects plant resistance to stress-factor action. Biochem. Soc. Trans. 28:922924.

Tzin, V. and G. Galili. 2010. New insights into the shikimate and aromatic amino acids biosynthesis pathways in plants. Mol. Plant 3:956-972.

UniProt Consortium. 2017. UniProt: The universal protein knowledgebase. Nucleic Acids Res. 45:D158-D169.

Vashisht, A.A., A. Pradhan, R. Tuteja, and N. Tuteja. 2005. Cold and salinity stress induced bipolar pea DNA helicase 47 is involved in 
protein synthesis and stimulated by phosphorylation with protein kinase C. Plant J. 44:76-87.

Veinger, L., S. Diamant, J. Buchner, and P. Goloubinoff. 1998. The small heat-shock protein IbpB from Escherichia coli stabilizes stress-denatured proteins for subsequent refolding by a multichaperone network. J. Biol. Chem. 273:11032-11037.

Verbruggen, N. and C. Hermans. 2008. Proline accumulation in plants: A review. Amino Acids 35:753-759.

Vogt, T. 2010. Phenylpropanoid biosynthesis. Mol. Plant 3:2-20

Wahid, A., S. Gelani, M. Ashraf, and M.R. Foolad. 2007. Heat tolerance in plants: An overview. Environ. Expt. Bot. 61:199-223.

Walch-Liu, P., L-H. Liu, T. Remans, M. Tester, and B.G. Forde. 2006. Evidence that L-glutamate can act as an exogenous signal to modulate root growth and branching in Arabidopsis thaliana. Plant Cell Physiol. 47:1045-1057.

Wang, J., P. Burgess, W.A. Meyer, S.A. Bonos, and B. Huang. 2017a. Differential physiological responses and genetic variations in fine fescue species for heat and drought stress. J. Amer. Soc. Hort. Sci. 142:1-9.

Wang, J., H.R. Juliani, D. Jespersen, and B. Huang. 2017b. Differential profiles of membrane proteins, fatty acids, and sterols associated with genetic variations in heat tolerance for a perennial grass species, hard fescue (Festuca trachyphylla). Environ. Expt. Bot. 140:65-75.

Wang, W., B. Vinocur, O. Shoseyov, and A. Altman. 2004. Role of plant heat-shock proteins and molecular chaperones in the abiotic stress response. Trends Plant Sci. 9:244-252.
White, P.J. and M.R. Broadley. 2003. Calcium in plants. Ann. Bot. 92:487-511.

Wilkinson, B. and H.F. Gilbert. 2004. Protein disulfide isomerase. Biochim. Biophys. Acta. Proteins Proteomics 1699:35-44.

Wittmann, H. 1982. Components of bacterial ribosomes. Annu. Rev. Biochem. 51:155-183.

$\mathrm{Xu}, \mathrm{C}$, Y. Xu, and B. Huang. 2008. Protein extraction for twodimensional gel electrophoresis of proteomic profiling in turfgrass. Crop Sci. 48:1608-1614.

Xu, Y., P. Burgess, and B. Huang. 2015. Root antioxidant mechanisms in relation to root thermotolerance in perennial grass species contrasting in heat tolerance. PLoS One 10:1-19.

Yamakawa, H. and M. Hakata. 2010. Atlas of rice grain filling-related metabolism under high temperature: Joint analysis of metabolome and transcriptome demonstrated inhibition of starch accumulation and induction of amino acid accumulation. Plant Cell Physiol. 51:795-809.

Zchut, S., M. Weiss, and U. Pick. 2003. Temperature-regulated expression of a glycine-rich RNA-binding protein in the halotolerant alga Dunaliella salina. J. Plant Physiol. 160:1375-1384.

Zhang, N., B. Zhao, H.J. Zhang, S. Weeda, C. Yang, Z.C. Yang, S. Ren, and Y.D. Guo. 2013a. Melatonin promotes water-stress tolerance, lateral root formation, and seed germination in cucumber (Cucumis sativus L.). J. Pineal Res. 54:15-23.

Zhang, Y., L. Xu, X. Zhu, Y. Gong, F. Xiang, X. Sun, and L. Liu. $2013 \mathrm{~b}$. Proteomic analysis of heat stress response in leaves of radish (Raphanus sativus L.). Plant Mol. Biol. Rpt. 31:195-203. 
Supplemental Table 1. Content of amino acids under $21 \mathrm{~d}$ of heat stress treatment compared with control in 'Predator' and 'Reliant IV' hard fescue.

\begin{tabular}{|c|c|c|c|c|}
\hline \multirow[b]{2}{*}{ Metabolite } & \multicolumn{4}{|c|}{ Amino acid content $\left[\right.$ mean $\pm \mathrm{SD}\left(\mu \mathrm{g} \cdot \mathrm{mg}^{-1}\right.$ dry weight $\left.)\right]$} \\
\hline & Predator_control & Predator_heat & Reliant IV_control & Reliant IV_heat \\
\hline Asparagine & $12.443 \pm 0.398$ & $8.483 \pm 0.211$ & $7.348 \pm 0.649$ & $6.005 \pm 0.413$ \\
\hline Valine & $0.145 \pm 0.013$ & $0.498 \pm 0.043$ & $0.145 \pm 0.019$ & $0.343 \pm 0.039$ \\
\hline Alanine & $0.598 \pm 0.019$ & $1.710 \pm 0.120$ & $0.760 \pm 0.058$ & $1.280 \pm 0.158$ \\
\hline Threonine & $0.213 \pm 0.017$ & $0.246 \pm 0.049$ & $0.095 \pm 0.006$ & $0.225 \pm 0.029$ \\
\hline Serine & $0.630 \pm 0.016$ & $0.645 \pm 0.033$ & $0.493 \pm 0.034$ & $0.560 \pm 0.059$ \\
\hline Tryptophan & $0.065 \pm 0.006$ & $0.188 \pm 0.018$ & $0.035 \pm 0.006$ & $0.150 \pm 0.018$ \\
\hline Glutamic acid & $2.170 \pm 0.143$ & $1.798 \pm 0.043$ & $1.153 \pm 0.115$ & $1.818 \pm 0.082$ \\
\hline Lysine & $0.270 \pm 0.036$ & $0.708 \pm 0.061$ & $0.240 \pm 0.024$ & $0.375 \pm 0.058$ \\
\hline Arginine & $0.300 \pm 0.024$ & $0.750 \pm 0.095$ & $0.663 \pm 0.085$ & $0.440 \pm 0.055$ \\
\hline Glycine & $0.060 \pm 0.000$ & $0.128 \pm 0.010$ & $0.085 \pm 0.006$ & $0.098 \pm 0.010$ \\
\hline Isoleucine & $0.718 \pm 0.041$ & $3.130 \pm 0.264$ & $0.748 \pm 0.056$ & $2.228 \pm 0.423$ \\
\hline Phenylalanine & $0.125 \pm 0.013$ & $0.454 \pm 0.036$ & $0.145 \pm 0.006$ & $0.408 \pm 0.035$ \\
\hline Aspartic acid & $0.768 \pm 0.029$ & $0.765 \pm 0.047$ & $0.478 \pm 0.015$ & $0.605 \pm 0.024$ \\
\hline Proline & $0.588 \pm 0.046$ & $7.498 \pm 0.439$ & $0.188 \pm 0.150$ & $6.113 \pm 0.742$ \\
\hline Leucine & $0.113 \pm 0.015$ & $0.520 \pm 0.073$ & $0.238 \pm 0.010$ & $0.325 \pm 0.053$ \\
\hline Tyrosine & $0.046 \pm 0.005$ & $0.132 \pm 0.008$ & $0.060 \pm 0.000$ & $0.118 \pm 0.005$ \\
\hline Histidine & $0.203 \pm 0.010$ & $0.238 \pm 0.008$ & $0.124 \pm 0.005$ & $0.192 \pm 0.013$ \\
\hline Glutamine & $0.800 \pm 0.070$ & $1.393 \pm 0.079$ & $0.495 \pm 0.021$ & $1.140 \pm 0.161$ \\
\hline Total amino acid content & $20.086 \pm 1.024$ & $32.462 \pm 1.966$ & $11.620 \pm 1.077$ & $23.041 \pm 1.644$ \\
\hline
\end{tabular}

